\title{
Yeni Mecrada Hegemonik Söylem: Erkeklik Krizinin Instagram'da Tezahürü
}

\author{
Işıl Kızılırmak Ata \\ Doktora Öğrencisi \\ kizilirmakisil@gmail.com \\ Mersin Üniversitesi Sosyal Bilimler Enstitüsü \\ 0000-0002-1856-0634
}

\section{Aslıhan Doğan Topçu \\ Prof. Dr. \\ aslihandt@mersin.edu.tr \\ Mersin Üniversitesi İletişim Fakültesi \\ 0000-0001-5538-314X}

\section{Abstract \\ Hegemonic Discourse on the New Media: The Manifestation of Masculinity Crisis on Instagram}

In social media where counter-hegemonic discourses can be produced and which give freedom to its users through the anonymity it provides, gender is represented by the reproduction of inequality and the construction of different experiences by the transformed identity. Instagram, which is differentiated from other social media applications by its user profile formed mainly by young people and by its effect on gender formation according to dominant references, is a fertile place with these specificities to analyse sexual identities. In this research, the discourses of accounts that produce Turkish-language content focused on masculinity were analysed. The focus of the analysis is on the relationship between the existing discourse on these accounts and the dynamics of the crisis of masculinity and the movements of men, deepened by structural problems such as unemployment and also by the momentum acquired by the feminist movement. The research results indicate that the masculinity of the analysed Instagram accounts is shaped by radicalized masculinism and hate speech towards women. The discourse becomes violent when it comes to any news item that is seen as a threat to masculinity.

keywords: masculinity, social media, masculism, Instagram, representation 


\section{Résumé}

\section{Discours hégémonique sur les nouveaux médias : la manifestation de la crise de la masculinité sur Instagram}

Dans les médias sociaux où les discours contre-hégémoniques peuvent être produits et qui donnent de la liberté aux utilisateurs par l'anonymat qu'ils offrent, le genre est représenté par la reproduction de l'inégalité et la construction des différentes expériences par l'identité transformée. L'Instagram qui est différencié des autres applications des médias sociaux par son profil d'utilisateur formé surtout par des jeunes et par son effet sur la formation du genre selon les références dominantes, est un lieu fertile avec ces spécificités à analyser les identités sexuelles. Dans cette recherche, ont été analysés les discours des comptes qui produisent des contenus en turc focalisés sur la masculinité. Le focus de l'analyse est sur la relation entre le discours existant sur ces comptes et les dynamiques de la crise de masculinité et des mouvements d'hommes approfondies par des problemes structurales comme le chômage et aussi par l'élan acquis par le mouvement féministe. Les résultats de la recherche indiquent que la masculinité des comptes Instagram analysés est formée par un masculinisme radicalisé et par un discours de haine envers la femme. Le discours devient violent dès qu'il s'agit de n'importe quelle actualité perçue en tant qu'une menace envers la masculinité.

mots-clés: la masculinité, les médias sociaux, le masculisme, Instagram, la représentation

\section{Öz}

Karşı-hegemonik söylemlerin de üretilebildiği ve sağladığı anonimlikle kullanıcılarına özgürlük alanı açan sosyal medyada toplumsal cinsiyet, hem eşitsizliğin yeniden üretilmesi hem de dönüşen kimliğin farklı deneyimleri kurmasılya temsil edilmektedir. Genç yoğun kullanıcı profili ve toplumsal cinsiyeti egemen atıflara göre biçimlendirmedeki etkisi ile diğer sosyal medya uygulamalarından ayrılan Instagram da bu nitelikleri ile cinsiyet kimliklerinin incelenmesi için verimli bir alandır. Bu çalışmada, Instagram'da erkeklik odaklı Türkçe içerik üreten hesapların söylemleri analiz edilmiştir. Analizin odağında, bu hesaplardaki söylemin, işsizlik gibi yapısal sorunların yanı sıra feminist hareketin kazandığı ivmeyle de derinleşen, erkeklik krizi dinamikleri ve erkeklik hareketleriyle ilişkisi, vardır. Çalışmanın bulguları, incelenen Instagram hesaplarındaki erkekliklerin radikalleşen biçimde maskülizm ile kadına yönelik nefret söylemiyle biçimlendiği yönündedir. Söylem, erkekliğe yönelik tehdit olarak algılanan herhangi bir gündemde şiddetlenmektedir.

anahtar kelimeler: erkeklik, sosyal medya, maskülizm, Instagram, temsil 


\section{Giriş}

Kullanııısına anonimlik ve sınırsızlık üzerinden sağladığı özgürlük alanı ile yeni medya, onun kendisini temsiline ve kolektif bir kimliğin parçası olmasına imkân tanımaktadır. Bu özgürlük alanı, toplumsal hiyerarşilerin yeniden üretimine koyduğu katkıyla tartışılmaya devam etse de, alanın dayatma nedeniyle gündelik hayatta deneyimlenemeyen performanslara imkân tanıdığı ve egemenin sesi dışındaki sesleri tanıdığı da aşikardır (Alemdaroğlu ve Demirtaş, 2004, s. 206). Toplumsal cinsiyet kimliklerinin yeni medyada temsili de, bu hegemonya-dışı söylemi sahiplenmekle ait hissedilen kategoriye içkin sayılan nitelikleri eşitsizliği yeniden üretecek biçimde ilan etmek arasında deneyimlenmektedir. Bourdieu (2014, s. 87-88), bedenin başkalarına takdiminin pratik deneyim ile meşru beden arasındaki mesafeyi belirlediğini ve kişinin toplumsal hayattaki başarısına katkı sunduğunu söylemektedir; kadınları sembolik nesnelere dönüştüren eril tahakküm, onları başkalarının bakışı tarafından var edilen bir konuma hapsederken sembolik bağlılık altında tutar.

Kadın bedeninin nesneleştirilmesinde kitle iletişim araçlarının rolü ve bu sürecin egemen erkekliğin yeniden üretimine etkisi, feminist hareketin etkisiyle 1960 'lardan beri tartışımaktadır. Bugün bu sürece dijital ortamlardaki temsil üzerinden bakıldığında, kadınlığın yine benzer bir hattan inşa edildiği görülmektedir ki, bu inşayı sosyal medyanın, özellikle gençler üzerinde, bedenin en güçlü denetim aracına dönüşmesinden bağımsız düşünmek mümkün değildir (Verrastro vd.,2020). Erkekliklerin dijital ortamlardaki temsillerinin incelenmesi ise daha yakın tarihin konusudur, ilk araştırma 1997'de yapıldıysa da kadınlık temsilleriyle karşılaştırmadan salt erkeklikleri inceleyen çalışmaların sayısı hâlâ çok değildir (Light, 2013; Rodriguez ve Hernandez, 2018). Hem gündelik pratiklerle doğrudan karşı karşıya olduğumuz bir alan hem de yıktığı sınırlar ve belirleme gücü ile sosyal medya, erkekliği sadece egemen erkekliğin yeniden üretimiyle değil çatışmalı yapısı ile de kurar. Sosyal medyayı hegemonik erkekliği yeniden üretmek için kullanan erkek hakları aktivistleri için, mecranın, özellikle feministler tarafından, karşı-hegemonik söylemler için kullanılması daha radikal ideolojiler ve söylemler geliştirmesi ile karşılık bulmaktadır (Nagle'dan aktaran Rodriguez ve Hernandez, 2018:2). Ging (2017) de, gerçek dünyadaki şiddet eylemleriyle de ilişkilendirilen web tabanlı radikal kadın düşmanlığı 'manosphere'in zehirli bir anti-feminist propagandayı sürekli güçlendirerek etki alanını genişlettiğine dikkat çekmektedir.

Kadınların sosyal medyayı eşitsizlik ve şiddete karşı yükseltilen sesin aracı olarak kullanışı, dünyadaki deneyimlere paralel biçimde Türkiye'de de, \#metoo gibi dijital eylemliliklerle ivmelenmiştir. Son yıllarda kadınlar ve LGBTi+'lar için sosyal medya, düzenledikleri yüksek katılımlı eylemlere dair haberleri yaygınlaştırılabildikleri ve örgütlenebildikleri en önemli mecradır. Özgürlük ve eşitlik talebinin, gündelik hayatta temas edilmeyen deneyimleri de görünür kılan sosyal medyada ilanı erkeklik krizine yeni bir kaynak kazandırmaktadır. Bu krizin 'gerçek dünya'daki kaynağında ise, ekonomi alanındaki belirsizlikle yükselen işsizlik, 
göçmenlerde cisimleştirilen güvenlik kaygısı ve siyasal alana yayılmış gerilim durmaktadır. Erkeklik krizinin egemen erkeklik söylemine karşı söylemlerin üretildiği bir alan olan sosyal medyadaki erkeklik tezahürleri üzerinden okunmaya çalışılması, kolektif kimliğin inşasına anın içinden bakma potansiyeli taşımaktadır. Sosyal medya hem toplumun yansıması olarak kabul gören erkekliklerin incelenebileceği hem de sağladığı anonimlikle hegemonik olmayan temsillerin görülebileceği bir alandır. Erkekler arasındaki reel farkları ortadan kaldırarak onları görece eşitleyen, pek çok erkek için ideal erkekliğe dair kurgunun deneyimlenebildiği bu alandaki temsilleri incelemek, bu deneyimin kolektif kimliğin inşasına etkisini ve ataerkil düzenden arzuladığınca pay alamayan erkeklerin krizle ilişkisini açığa çıkarma imkânı da sunmaktadır.

Betimleyici bir nitel araştırma tasarımına dayanan bu çalışma, Connell'ın (2012, s.6), çoklu erkeklik deneyimlerinin toplumsal hayata etki eden tüm kurumlar ve ortamlarda olduğu gibi, kitle iletişim araçları ve popüler kültürde de incelenmesinin, erkekliği sabit ve tarih dışı bir konum olarak anlamlandırmanın önüne geçebileceği fikrinden hareketle, kullanıcılarının yaş grubu ${ }^{1}$ ve kullanım pratikleriyle bir 'yeni'yi temsil etme potansiyeli bulunan Instagram'da üretilen erkeklik söylemleri ile erkeklik kriz dinamikleri arasındaki ilişkiyi anlamayı amaçlamaktadır. Bu amaç kapsamında araştırma temel olarak, incelenen hesaplardaki söylemlerin ilişkilendiği erkeklik kategorileri ile erkeklik hareketlerinin genç kullanıcı yoğun bir mecrada farklı erkekliklere ne derece alan açtığına, kadın ve LGBTí+'lara yönelik bakışın erkeklik inşasındaki yerine odaklanmaktadır.

\section{Dijital Dünyada Erkeklik Temsillerine İlişkin Çalışmalar}

Toplumsal cinsiyetin sanal ortamlardaki temsillerini konu edinen ilk çalışmaların sonuçları, ortamın kullanıcılarına cinsiyet konusunda daha geniş bir özgürlük tanıdığı yönündedir. Anonim kimlikler baskı ve çelişkiyi ortadan kaldırabileceği gibi, var olan cinsiyet kategorilerine meydan okuma potansiyelini de açığa çıkarır (aktaran Alemdaroğlu ve Demirtaş, 2004, s. 214). Ancak ilerleyen dönemlerde sanal ortamların, toplumsal cinsiyet kimlikleri arasındaki hiyerarşinin yoğun olarak deneyimlendiği alanlar olduğu ortaya konmuştur.

Alandaki güncel çalışmalar da görsel tabanlı sosyal medya uygulamalarının toplumsal cinsiyet kimliklerini kalıp yargılara göre yeniden üretmedeki etkisine odaklanmaktadır. Feltman (2018, s. 3-4), kadın ve erkek Instagram kullanıcılarının fotoğraf seçimlerinin farklılaştığını belirtmektedir. Verrastro vd., (2020, s.4), Instagram'ın kadın ve erkeklerin kendilerini toplumsal beklentilere göre şekillendirme etkisiyle diğer sosyal medya uygulamalarından ayrıldığına değinmektedir.

Görsel tabanlı bir sosyal medya uygulaması olarak Instagram, kendini ifade etme intiyacını sözel olmayan bir forma taşınmaktadır. Cep telefonu uyumlu

1 Nisan 2020 itibariyle, Instagram kullanıcılarının \%64'ü 18-34 yaş aralığındadır (https://www.statista.com/statistics/325587/instagram-global-age-group/). 
bir uygulama olması yaygınılk kazanmasını sağlamış, günlük deneyimlerin parçası haline gelerek sosyal görünürlügün aracısına dönüşmüştür (Rodriguez ve Hernandez, 2018, s. 3). Feltman (2018, s.5), Instagram'ın yarattığı etkinin çevrimiçi paylaşımdan çok etkileşimle ilgili olduğunu belirtmektedir. Verrastro vd., (2020, s.3) ise, etkileşimin yarattığı değer duygusu nedeniyle popülerlik yarışına girilen Instagram'ın yoğun kullanımının narsistik özellikler ve endişeyle ilişkisine dikkat çekmektedir.

Sosyal medya, toplumsal cinsiyet ilişkilerindeki eşitsizliğin açığa çıkarılması amacıyla kadın ve erkek kullanıcıların deneyimlerine odaklanan çalışmalara konu olmuş ancak bir erkeklik üretim mekânı olarak incelenmesi yakın dönemde yoğunlaşmıştır. Alanyazındaki ilk araştırmalar, alanın cinsiyetlere özgürlük tanıdığı fikrinden hareketle, eşcinsel erkeklerin sohbet odalarındaki deneyimlerine ve cinsel sağlığın dijital ortamlarla ilişkilerine odaklanmaktadır (Shaw, 1997; Yang, 2000). Bunları eşcinsel erkeklerin sanal porno deneyimleri, heteroseksüel erkeklerin reklamlara yönelik tutumları, pornografinin hegemonik erkekliğin inşasındaki yerine odaklanan (Mowlabocus, 2007; Garlick, 2010; Morgan, Richards ve VanNess, 2010) çalışmalar takip etmiştir. Light (2013) teknolojinin cinsiyetlendirici yapısının açığa çıkarımasının erkekler arası hiyerarşinin inşasını kavramaya katkı koyacağına değinmiştir. Ging (2017, s. 5-6) ise, anonimliğin düşmanca ve yasadışı erkeklik performanslarının sergilenmesi intimalini kolaylaştırdığına dikkat çekmektedir. Anonim tecavüz tehditleri ve fantezi performanslarından görüntüler göndererek kadınlara boyun eğdirmeye çalışma gibi hegemonik erkeklik inşasının merkezinde yer alan eylemler, sosyal medyanın teknolojik gücüyle yoğunlaştırılabilir ya da istendiğinde silinebilir. Bu yok etme imkânıyla beden ve konumun saklanması/ yeniden tasarlanması yasal süreçlerde cezasızlığa olanak tanımaktadır. Rodriguez ve Hernandez ise (2018), Instagram'da kadın bedeninin nesneleştirilmesi ve kadın düşmanı söylemleri hegemonik erkekliğin inşası bağlamında incelemiştir.

Türkiye'de dijital ortamlarda erkeklik temsillerinin incelendiği ilk çalışmalardan biri, sohbet odalarındaki anonimliğin özgürleştirme potansiyelini erkek profilleri üzerinden inceledikleri çalışmalarıyla Alemdaroğlu ve Demirtaş'a (2004) aittir. Facebook'ta erkekliğin kadınlara karşı organize olma bağlamında temsiline (Demez, 2011), Facebook taraftar sayfalarında hegemonik erkeklik inşasına (Akbaş, 2012), ErkekMuhabbeti'nin toplumsal cinsiyet çalışmalarına erkek katılımı açısından incelenişine (Sancar, 2017), sosyal medyada çıplak erkek bedeninin sunumuna (Doruk, 2019), Instagram'da dijital babalığa (Gökaliler ve Özer, 2019), erkekadam.org bloğunda "erkeklik evreni"nin betimlenmesine (Elgün, 2020) ve Twitter'da \#erkekyerinibilsin etiketiyle paylaşılan içeriklerdeki erkeklik söylemlerine (Öztürk, 2021) odaklanan çalışmalar sosyal medyada erkeklik temsillerine dair ufuk açıcı katkılar ortaya koymuştur. Instagram'da \#erkeklik etiketini kullanan profillerinin kullanıcı tipleri doğrultusunda kategorileştirilmesini amaçlayan çalışmasında Elgün (2020), etiketin en çok bireysel hesaplarca kullanıldığını ve egemen erkekliğin yeniden üretiminin yanında eleştirel erkeklik ile feminist söylemlere de alan açıldığını belirtmektedir. 
Alanyazında sosyal medya ile erkeklik ilişkisine dair çalışmaların sayıları artıyorsa da, Rodriguez ve Hernandez (2018 s.2), hegemonik erkeklik, hipermaskülinite ve toksik erkekliğe dair performansların Tinder, Match.com, Twitter ve Facebook dahil olmak üzere farklı sosyal medya platformlarında çalışıldığına ve Instagram'da sadece erkekliğe odaklanan araştırmaların sayısının azlığına değinirler. Bu uygulamada toplumsal cinsiyet temsillerini konu alan son çalışmalar da (Verrastro vd., 2020), saptamayla uyumlu olarak, genç kadın ve erkeklerin Instagram'daki beden ve güzellik algılarına ilişkindir.

Genç kullanıcı yoğun bir sosyal medya uygulaması olarak Instagram egemen dışı kimliklere alan açabilme potansiyeli bulundurmasına karşın tüm dünyada yayılan kadın düşmanı internet performanslarının da üretilebildiği bir mecradır. Instagram'da "erkek", "erkeklik", "maskul/maskül" terimlerini içeren adlara sahip anonim hesapları ${ }^{2}$ erkeklik konumları ile erkeklik kriz dinamikleri ve şiddet söylemi arasındaki ilişkiye odaklanarak inceleyen bu çalışmanın Türkiye'de erkeklik kimliklerinin sosyal medyada yeniden üretimine dair güncel bir perspektif sunarak alanyazına katkı sunabileceği düşünülmektedir.

\section{Sancılı Bir İnşa Olarak Erkeklik ve Eleştirel Erkeklik Çalışmaları}

Toplumsal cinsiyet eşitsizliğini kavramak için tipik bir erkeklik kurgusu üzerine yoğunlaşıp "daha az ayrıcalıklı" konumda olan kadınları anlamanın yeterli olmayacağını belirten Connell (1998; 2019), ayrıcalıklı konuma sahip erkekleri de anlamak gerektiğini vurgulamıştır. Connell'a (2019, s. 70-72) göre, tanımları kurumların ve ekonomik yapıların tarihi içine kök salmış erkekliği anlamak bir düşünce yapısı veya kişisel kimliği anlamayı aşarak, örgütlü toplumsal ilişkilerin bütününü düzenleyen dünyayı da anlamaktır. Messerchmidt (2019, s. 39-40), toplumsal cinsiyet kimlikleri arasında ırk, yaş, cinsellik ve milliyetin yarattığı farka odaklanan tartışmaların ancak 1980 'lerin ortasından itibaren başladığına değinmektedir.

Eleştirel erkeklik çalışmaları, eril tahakkümü salt kadının tabi kılınışı üzerinden okuyan ve iktidar konumunu muğlaklaştıran toplumsal cinsiyet çalışmalarının kimlik inşasına yaklaşımını derinleştirmek için alan açmıştır. Sancar'ın ifadesiyle (2009, s.11), "toplumsal iktidar ilişkilerinin hem öznesi, hem de nesnesi olmak durumda olan erkeklik deneyimlerini anlamadan, modern kapitalist toplumların cinsiyet rejimlerini anlamak" olası değildir. Hooks (2018, s. 40-41), erkeklerin daimi "muktedirler", "ayrıcalıklı kazananlar"; ataerkiye itaatkârlıkla eril hakimiyetin sürdürülmesinin biricik sorumlusu olarak kodlanmasının, ataerkinin erkeklikle ilişkisini görünmez kılacağını vurgulamaktadır.

2 ilgili hesaplar çalışmanın örneklem başlığında detaylandırılmıştır. 


\section{Erkeklik Kategorileri ve Eril Tahakkümü Kurumsallaştıran Hegemonik Erkeklikler}

Connell (1998;2019), farklı erkeklik deneyimlerini, hem kadın hem de diğer erkekliklerin kimliklerinde etkin rol oynayan hegemonik erkeklik, suç ortağı erkeklikler, marjinal erkeklikler ve madun/tabi kılınan erkeklikler olarak kategorize eder. Suç ortağı erkeklikler, ataerkilliğin inşasında hegemonik erkeklik kadar aktif değildir ancak sessizlikle kadının ikincilleştirilmesinden paylarını alıllar ve erkeklerin büyük çoğunluğu bu sınıflandırmada yer alır. Marjinal erkeklikler, ırk, etnisite veya sınıfsal açıdan iktidar karşısında dezavantajı konumdadır, her zaman baskın hegemonik grubun iznine tabiidir. Toplumsal cinsiyetin sınıf ve ırk gibi yapılarla etkileşimi erkeklikler arasında farklı ilişkisellikler yaratır. Madun erkeklikler heteroseksüellik dışı cinsel yönelim nedeniyle ataerkilliğin erkeklere sağladığı ayrıcalıklı konumdan en az fayda gören gruptur. Maduniyet, toplumdaki kültürel tahakkümle ilişkilidir ve homoseksüel erkeklerin, heteroseksüel erkeklere tabi kılınması, homoseksüelliğin kültürel olarak damgalanmasından çok daha fazlasını imlemektedir.

Erkeklikler arası hiyerarşinin zirvesi olarak hegemonik erkeklik, toplumsal ilişkilerin örgütlenmesinde sadece kadınlara karşı değil diğer erkekliklere karşı da baskın gelmeyi içerir. Hegemonik erkeklik, kültürel, tarihsel ve coğrafik farklılıklar gösterebilmekle beraber, temelde erkeklerin tahakkümünü ve kadınların tabi kııımışığını yeniden üreten, dolayısıyla ataerkilliğin meşruiyet sorununa yanıt üreten bir toplumsal cinsiyet pratiğidir (Connell, 2019, s. 77-78). "iktidarı elinde tutan erkeklerin sahip olduğu erkeklik imgesine işaret eden bir kavram" olarak hegemonik erkeklik, sayıca az görülmekle birlikte, geniş erkek kesiminin onayıyla, devlet, ordu, aile gibi kurumlarca meşrulaştırılan değerler aracılığıyla inşa edilir (Sancar, 2009, s.27-32). Çağdaş hegemonik erkekliğin başat özelliği, tabi kılınmış erkekliğin en görünür biçimi olan eşcinselliğin karşısında, heteroseksüel kimliğe sahip olmaktır (Connell, 1998, s. 249).

Illerleyen dönemde Connell ve Messerchmidt (2005) kavramı yeniden tanımlarken hegemonik erkekliğin ebedi bir statü olmadığına, diğer kategoriler gibi dönüşüme açık olduğuna vurgu yaparlar. Onu diğer kategorilerden ayıran dinamik olmadığı yönündeki yanlış okumadan çok erkeklikler arası hegemonik mekanizmaları açığa çıkarmadaki işlevselliğidir. Kavramın odağında, zaman ve kültürden bağımsız, bir örtüşen değerler toplamı değil, dönemin ruhuna uygun olarak onaylanan nitelikler vardır. Hegemonik erkekliğin fiziksel şiddet gibi toksik eylemlere atıfta bulunmasının şaşırtıcı olmadığını ancak şiddetin her zaman hegemonik erkekliği tanımlamada kullanılamayacağını belirterek hegemonyanın farklı yapılanışları olduğuna dikkat çekerler. Messerchmidt (2019, s. 90-93) baskın erkekliğin her zaman eşitsiz cinsiyet ilişkilerini meşrulaştırmanın öznesi olmayacağına, tahakkümcü erkekliğin pratiğe dökülen toksiklik olduğuna değinir ${ }^{3}$. Odağa şiddet,

3 Toksik erkeklik, "fiziksel ve mental güçlülük, hisleri dışa vurmamak, şiddete eğilim gibi özellikler, bunların tam tersinin kadınsı olduğu iddiasına ve kadınlığın reddine dayanır". Kavram bu yönüyle kötücül özellikleri doğayla ilişkilendirip erkekliklerin değişken yapısını boşa düşürme potansiyeli taşımaktadır (Günay- Erkol, 2018, s.9). 
saldırganlık ve benmerkezcilik yerleştiğinde, hiyerarşik ilişkileri rızayla meşrulaştıran hegemonik erkeklikler ile tahakkümcü erkeklikler arasındaki fark belirginleşir.

Hegemonik erkekliğin yeniden formülasyonunu tartıştığı metninde Messerchmidt (2019, s. 130-137), başat erkeklikler kavramını detaylandırır. Yerel, bölgesel, küresel ölçekte en çok onaylanan yerleşik deneyim olarak başat erkeklik her daim toplumsal cinsiyet egemenliğiyle bağlantılı olmayabilir. Hegemonik erkekliği Bourdieu'nun habitus, sermaye ve alan kavramlarıyla tartışan Coles'a (2009) göre, habitusun sürekli norm dayatmasını aşmak olasıdır. Mozaik erkeklik kavramı, bu olasılıkla, hegemonik erkekliğin gerekleriyle müzakere edip güçlü alanlara vurgu yaparak, yeniden baskın olma biçimde inşa edilir. Mozaik erkeklik hegemonik erkekliği tanır, kendisindeki eksik parçayı, doğru sermayeye yatırım yaparak tamamlayabilir, bu sayede güç ve statü sağlayabilir.

Eleştirel erkeklik çalışmalarına dair son katkılardan biri Borkowska'nın (2009) içerimli erkeklik yaklaşımıdır. İçerimli erkeklik, önceki nesillerce reddedilen kimi niteliklerin yeni nesil erkeklerce sahiplenilmesini ve erkekliğin bu özellikleri içerecek biçimde genişlemesini ifade etmektedir. Erkekliğe içkin nitelikler tarihsel eğilimlerle şekillendiğinden dönüşebilir; erkekler arası ilişkilerde daha az tahakküm, duyguları paylaşmada çekincesizlik veya homofobinin eskisi kadar güçlü olmayışı buradan hareketle okunabilir (Günay- Erkol, 2018, s.10-11). Ancak orta sınıf, beyaz heteroseksüel erkeklerin sınırlı deneyimini tanımladığından, cinsiyet güç ilişkilerine dair bir değişim potansiyeli barındırması olası görünmemektedir (Ging, 2017, s.4).

\section{Erkeklik Hareketleri: Ataerki, Feminizm ve Konumlar}

Erkeklik deneyimlerini daha net anlayabilmek için, ilişkilendikleri konum/ hareketlerin seyrine de bakmak gereklidir. Bozok (2009;2011), Messner (1997) ve Clatterbaugh'ın (1990) sınıflandırmalarına referansla, hareketlerin feminizmle ilişkisini odağa alan üçlü sınıflandırmayı şöyle özetler: Erkeklikçi (masculinism), erkek kurtuluşçu (male liberation) ve pro-feminist konumlar. Erkeklikçilik yaklaşımını sahiplenenler, biyolojik belirlenime atıfla, erkeğin doğası gereği üstün olması gerektiğini savunurlar ancak onlara göre erkek egemenliği hiçbir zaman tam anlamıyla gerçekleşememiştir. Biyolojik belirlenimcilik ve yaradılışçlıkla ilişkilenen söylemleri, ataerkillik savunusu ve kadın düşmanlığından beslenir. Ataerkil sistemin mutlak olduğu savunusunu feminizm ve queer harekete yönelttikleri nefret söylemi ile yüceltirler ${ }^{4}$. Erkek kurtuluşçuluğu yaklaşımı, kadınların ve LGBTi+'ların ikincilleştirilmesini görmezden gelip, ataerkil sistemin erkeklere verdiği zarara odaklanır. Buna göre, savaşta yaralanmaktan sürekli güçlü ve sert görünme zorunluğuna dek tüm mağduriyetler ataerkilliğin erkeklik rolleri nedeniyle gerçekleşmektedir. Yıkımın kaynağını erkekliğin özünden uzaklaşmış olmakta arar, ataerkil olmadığını

4 Selek (2018, s. 136), Gourarier'e atıfla, kadınların elinde olduğuna inandıkları iktidarı geri almak için örgütlenen maskülinist grupların kapalı eğitimler de düzenlediğine, gerek duyulduğunda kullanmak üzere şiddeti sahiplendiğine değinmektedir. 
kabul ettikleri sağlıklı erkekliğin özüne dönmeyi amaçlarlar. Üçüncü sınıflandırma ise pro-feminizmdir. Pro-feministler ataerkil sistemin kadınlar ve eşcinselleri ikincilleştirdiği bilinciyle, feminizm ve queer hareketleri destekler, tartışmalarını erkekliğin ataerkil sistemdeki konumunu kavramak üzerinden sürdürürler.

Bu politik konum/hareketler, büyük oranda, II. Dalga Feminizm'in erkekler cephesinde yarattığı yankıdan doğmuştur. Messner (2016, s.8), erkek kurtuluşçu hareketin, 1970'lerde geleneksel erkeklik anlayışlarını eleştirmek üzere çıktığı yolda, pro-feminist ve anti-feminist gruplara ayrıldığını söyler. I. Dalga Erkek Hareketi olarak anılan bu süreçte, erkeklerin değişimi yoluyla ataerkilliğin geriletilebileceği hatta yıkılabileceği tartışılmışırı. Ancak 1990 'ların sonunda ortaya çıkan II. Dalga Erkek Hareketi ile alınan yoldan geriye düşülmüş, erkekler yeniden iktidarı hedeflemiştir (Sancar, 2009, s. 28). Adams ve Savran, 1970'lerdeki erkek hareketlerinin eşitlikçi söyleminin aksine, 1990'ların talebinin erkeklerin feminizm eliyle kadınsılaştıııımasını durdurma olduğunu belirtirler (Onur ve Koyuncu, 2004, s.37).

\section{Erkekliğin Kırılgan Zemini ve Kriz Dinamikleri}

Toplumsal cinsiyet ilişkilerinin tarihsel dönüşümünü çıkar çatışmalarına odaklanarak değerlendiren Connell (2019, s.158), erkeklerin şeref, itibar ve hükmetme yetkilerini aldıkları ataerkiyle kurdukları bağın ne denli köklü olduğuna değinir. Bu bağın yitiminden duyulan kaygı iki şiddet odağını harekete geçirir: Ayrıcalıklı grubun üyelerinin tahakkümü devam ettirebilmek için kadınları hedef alan şiddete başvurması ve erkekler arası toplumsal cinsiyet ilişkilerindeki şiddetin yükselişi. İkinci odak sadece savaşları, silahlı saldırıları kapsamaz. Eşcinsel erkekleri hedef alan şiddette olduğu gibi, bir sınır çizme ve dışlama aracı, grup mücadelesinde erkekliği koruma ve kanıtlamanın yoludur. Connell (2009, s.161-162), modern erkekliklerin kriz eğilimlerinin, "erkeklik krizi"nden ayrı olarak, egemen erkekliğin yeniden tesis edilmesi girişimlerinin tetikleyicisi olabileceğini vurgular. Kriz eğilimlerinin en gözle görülür kanıtı, iktidar ilişkilerindeki dönüşümde; "ataerkil iktidarın meşruiyetinin tarihsel olarak çöküşü ve kadınların özgürleşmesi için dünya çapında başlatılan hareket"tedir. Bu kriz eğiliminin çıktısı, meşruiyet stratejilerini yeniden tahkim için erkeklik kültlerine yönelmek de feminist reformları desteklemek de olabilir.

Üretim ilişkileri kriz eğilimleri için güçlü bir damar oluşturur. Kadınların iş gücüne katılımı artsa da emeğin cinsiyete dayalı bölüşümü ve mülkiyetteki eşitsizlik sürmektedir. İşsizlik, fiziki veya teknolojik dezavantajın yarattığı farkla geride kalacağını, ataerkil çıkarları ile arasındaki hattın kırılganlaştığını düşünen erkeklik için üretim ilişkilerinin belirsiz yapısı gerilim kaynağıdır. Ataerkil toplumsal düzen karşısında cinsel özgürlüklerin görünürlügü bir diğer kriz eğilimi alanıdır. Kadınların beden denetimine karşı mücadeleleri, cinsel haz talepleri ve heteronormatiflik dışı cinsel pratiklerin mücadelesi kateksis ilişkilerini yeniden düzenlemiş̧ir. Bu kriz eğilimleri değişen erkekliklerin perspektiflerini sunmakla birlikte, sürecin modern erkek rolü imgeleri ya da gerçek erkeklik mitlerinin yeniden üretilmesinden daha geniş bir hatta sahip olduğunu, iktidara içkin tüm alanları kapsadığını gösterir (Connell, 2019, s. 163-164). 
Erkeklik krizi, modernlik değerlerinin erkeği üstün kılacak zemini yok etmeye başlaması karşısında duyulan korku ve endişeyi ifade etmektedir. Erkek üstünlüğünü tahkim mücadelesi "oldukça istikrarsız, kırılgan cinsiyet konumları"nı açığa çıkarmaktadır (Sancar, 2009, s.115). Bourdieu (2014, s. 68-70), erkeklerin her koşulda erkekliğini ispata zorlayan sürekli bir gerilim içinde bulunmalarının eril imtiyazın olumsuz yanı olduğuna değinirken, erkeklik krizinin kaynağını da açıklamaktadır. Gerekliliklere tabi erkeklik topluluğunda şeref, ayrıcalık kazanma amacıyla kamusal alandaki fırsatları değerlendirme intiyacı doğurmaktadır. Kadının erdemi bekaretle işaretlendiğinden şerefi yalnızca korunup kaybedilebilendir. Dolayısıyla, eril değerlerin yüceltilmesiyle kadınlıkla ilişkilenen kaygı arasında doğrudan bir ilişki vardır: "Böylelikle her şey imkânsız erillik idealini muazzam bir kırılganlık kaynağına dönüştürmek için bir araya gelir". Bourdieu, erilliğin görünür işaretlerini üretmekle erilliği sergileyip sınamanın ardında paradoksal biçimde bu kırılganlığın olduğunu açıklar. Erkeksi dayanışmanın güçlenmesini sağlayan erkeklik sınavları, erkekler grubuna aidiyet tasdiki, kimliğin yeniden üretim mecralarından olan sosyal medya platformları üzerinden de okunmaya açıktır.

\section{Araştırma Tasarımı}

Betimleyici bir nitel araştırma olarak tasarlanan bu çalışmada, Instagram'da erkeklik odaklı içerik üreten hesapların söylemleri, çalışmanın kuramsal çerçevesinden hareketle, erkeklik kategorileri ve hareketlerine aidiyete odaklanılarak incelenecektir.

\section{Amaç ve Varsayım}

Çalışmanın amacı, Instagram'da üretilen erkeklik söylemlerini erkeklik krizi dinamikleri bağlamında, erkekliğin inşa süreçleri ve erkeklikler arası tahakküm, çatışma ve dayanışma süreçlerini de anlamaya çalışarak, incelemektir. Bu amaçtan hareketle çalışmanın yanıt aradığı sorular şunlardır: Instagram'da 'erkeklik' terimini kullanarak içerik üreten sosyal medya hesaplarındaki egemen söylem hangi erkeklik kategorileri ile ilişkilidir? Bu hesaplarda tariflenen temel erkeklik nitelikleri nelerdir ve onlara sahip olmakla 'gerçek erkek' olmak arasındaki ilişki nasıl kurulmaktadır? Hesaplarda -varsa- ötekileştirici söylem kim üzerinden üretilmektedir? Hesaplar çalışmanın kuramsal kısmında yer verilen erkeklik sınıflandırmalarından hangisine dahil edilebilir? Sosyal medyadaki erkeklik içerikleri yekpare bir erkeklik söylemi mi üretmektedir yoksa genç kullanıcı yoğunluğuna sahip Instagram'da farklı erkeklik söylemlerine yer var midır?

Çalışmanın varsayımı, son dönemde farklı dinamiklerle derinleşen erkeklik krizinin sosyal medyadaki erkeklik söylemleriyle bağına odaklanır ve birbiriyle ilişkili iki hatta sahiptir. Bu varsayımlardan ilki, günümüzde kimliğin inşasındaki etkisi diğer tüm iletişim araçlarından daha etkili olan sosyal medyada bir kolektif kimlik olarak erkekliğin, bu krizi bertaraf etmeye çalışırken görünür 
kıldığı, avantajlı konumunu yeniden elde etmek için kendisine içkin gördüğü değerleri yüceltme yoluna gittiği, ikincisi ise başat düşmanın kadınlık ve ideal erkeklik değerleriyle çelişen erkeklikler olduğu, bundan hareketle erkeklik konumunun 'o olmayan'ı işaretlemekle kurulduğudur.

\section{Örneklem ve Yöntem}

Bu çalışmanın örneklem alanı olarak Instagram'ın belirlenmiş olmasının iki nedeni vardır: Bunlardan ilki, toplumsal cinsiyet kimliklerini toplumsal beklentilere göre şekillendirmeye daha fazla olanak sağlamasıyla diğer sosyal medya uygulamalarından ayrımasıdır. İkinci ve daha önemli neden ise, genç kullanıcı sayısının diğer sosyal medya uygulamalarından fazlalığı ile bir 'yeni'yi temsil etme potansiyelinin oluşu ve verili erkeklik krizi dinamiklerinin tezahürleriyle cinsiyet hiyerarşisinin geleceğine dair tespitlerde bulunmaya imkân sağlamasıdır.

Çalışmada, zengin bilgi yüklü durumların açıklanması ve örüntülerin derinlemesine analizine imkân tanıyan amaçlı örneklem yöntemi (Patton, 2014:242) kullanılmıştır. Çalışmanın örneklemi, Instagram'da Türkçe içerik üreten ve içerik oluşturma amacına uygun olarak "erkek", "erkeklik", "maskul/maskül" terimlerini içeren adlara sahip hesaplar içinde 31/04/2020 tarihi itibariyle en çok takipçiye sahip olan @maskulist.tr, @erkekkanali, @erkekadamsitesi, @1maskulist, @ erkek.cemiyeti, @erkekgibi, @masculinity.tr, @maskulizmturkiye, @maskulendusunce ve @maskulizm_esitlik ile sınırlıdır ${ }^{5}$. Takipçi sayısından bağımsız olarak, hesap adıyla örtüşmeyerek bağlam dışı içerik üreten ve reklam alan/ürün tanıtımı yapan hesaplar örnekleme dahil edilmemiştir.

Örneklemi oluşturan Instagram hesaplarının içerik üretmeye başladıkları tarihten 31/08/2020'ye kadar tüm gönderileri çalışmanın amacına uygun olarak, nitel metin analizi ile incelenmiştir. Yöntem, her bir hesaba ait söylemin, erkeklik kriz dinamikleriyle ilişkilendirilen gündemler başta olmak üzere, süreç içindeki seyrinin çok yönlü olarak incelenmesine imkân sağlayışı nedeniyle tercih edilmiştir. İçeriklere dair veriler kategorize edilerek analiz edilmiştir.

\section{Instagram'da Erkeklik İnşasına Dair Bir Analiz: Düşmanlaştırılan Kadınlık, Krizdeki Erkeklik}

Çalışmanın örneklemini oluşturan Instagram hesaplarında 31/08/2020 tarihine dek paylaşılmış toplam 3886 gönderi incelenmiştir. İlk olarak, her bir hesaba ait gönderiler, çalışmanın sorularına yanıt oluşturacak biçimde analiz edilmiştir. Ardından örnekleme dahil tüm gönderiler kadınlar ve feministler, ideal erkeklik kurgusu, erkekliğe dair sorunlar ve çözüm önerileri ile erkekliğin gelecek tahayyülü kategorilerinde incelenmiştir. Bu bölümde öncelikle, ilgili hesaplara dair genel bir çerçeve çizilecektir.

5 Instagram'ın örneklem alanı olarak belirlenme nedenleri belli olmakla birlikte, Twitter ve Facebook da amaca uygun olarak taranmıştır. Bu uygulamalarda örneklem niteliklerini sağlayan hesaplar çalışmada incelenen Instagram hesaplarına bağlıdır. Instagram için üretilen içerikler diğer uygulamalardaki hesaplarda yeniden paylaşılmaktadır. 
Toplumsal beklentiler karşısında erkekliklerin mağduriyetini görünür kılmayı amaçlayan @maskulist.tr isimli hesap 01.06.2017'den beri içerik üretmekte ve maskülizmi, "toplumsal cinsiyet eşitliği adına erkek haklarını savunmaya yönelik toplumsal teori ve politik hareket tarzı" olarak tariflemektedir ${ }^{6}$. İdeal erkekliğe dair beklentiler "erkek adam bale de yapar zeybek de oynar"7 ve "renklerin cinsiyeti yoktur" 8 iletileri ile reddedilmektedir. Toplumun iş cinayetlerinde yaşamını yitiren, sünnetle istismar edilen, intihardan başka çaresi kalmayan erkekleri görmezden gelişi eleştirilir. @maskulist.tr'ye göre bu tabloda asıl vahim olan, erkeklerin görünmez kılındıklarının bilincinde olmayışlarıdır ${ }^{9}$. Hesapta, özellikle kadın cinayetlerine verilen tepkilerden yola çıkarak müphem düşmanlar yaratıldığını, erkeklerin şiddet gördüğ̈̈ haberler aracılığıyla faili muğlaklaştıran içerikler üretildiğini söylemek mümkündür. Nafaka ve velayet davaları sıklıkla içerik üretilen başlıklardandır ve "Yargıtay resmen şunu diyor, "aldatılıyorsan ve çocuğunu görmeye devam etmek istiyorsan boşanma, bunu kabullen, aldatılmayı sindir."10 "Süresiz nafakanın ve mevcut nafaka kanununun insanlık dışı olduğunu artık herkes anlamalı."11 iletilerinde olduğu gibi kadınlar lehine düzenlendiği savlanan kanunların erkekler açısından adaletsizlik yarattığı vurgulanmaktadır. Feminizm gerekli bir mücadele olarak tariflenmekte ancak feminist eylemler erkekleri şiddet üzerinden tektipleştirmeleriyle eleştirilmektedir. @maskulist.tr, kaldırılamayan yüklere dönüşen erkeklik ödevlerine karşıdır; marjinal ve madun erkeklikleri tanır, hegemonik erkekliğin tahakkümünü reddeder, LGBTi+ mücadelesini destekler. Hesap kadına yönelik şiddetin karşısına failin de erkek olduğu şiddeti yerleştirdiği içeriklerinde maskülizme yaklaşsa da, erkek kurtuluşçu söylemlere sahiptir.

Çalışmanın örneklemine dâhil hesaplar içinde, içerik üreticilerinin gerçek kişiler olarak görünür olduğu tek hesap 09.04.2017'den beri etkin olan @erkekkanali'dır. Üreticiler baskın görünme kaygısı güdülmeyen fotoğraflarda, yemek yapmanın sırlarına, yoganın iyileştiriciliğine dair bilgiler paylaştıkları içeriklerde görünmektedirler. iç̧eriklerde egemen erkekliğe dair atıflar/beklentiler, özellikle toksik erkeklik tezahürleri eleştirilmekte, bunları yok saymayan erkeğin mutlu olamayacağı ifade edilmektedir: "Güvensiz bir adam çöker ya da doğasına uygun olarak saldırıya geçer. Saldırır, küfreder ve ezilir. (...) Köklenmiş bir erkek yanlış olmayı ve sorgulanmayı tehdit olarak görmez ve küçümsemez"12. Kitap, film, kişisel bakım, kas gücünü vurgulayanların dışındakileri de kapsayan spor önerilerinde bulunulmaktadır. Illişkilere dair içerikler genellikle kadın konuklarla üretilmektedir. Hesapta sürekli eşitlik vurgusu yapıldığı görülmekle birlikte, "kadınları içeriden fethetmenin yolu, astroloji!"13 , "kadınların kullandığı görsel dolandırıclık yöntemleri"14 içeriklerinde de görüldüğü gibi tektipleştirilmiş kadın söylemine yaslanıldığı

6 https://www.instagram.com/p/B-4bk8ynV8o/

7 https://z-p15.www.instagram.com/p/B0a6oSpnJjO/

8 https://z-p15.www.instagram.com/p/Bz5fYLOH6EU/

9 https://www.instagram.com/p/B5CrjrMH1qB/

10 https://z-p15.www.instagram.com/p/BsOxpuRHLHn/

11 https://z-p15.www.instagram.com/p/Bo4kcgyHYn8/

12 https://www.instagram.com/p/B5-VAfdAb8y/

13 https://z-p15.www.instagram.com/p/CGCopyPgoUS/

14 https://z-p15.www.instagram.com/p/CANrH3tggT」 
açıktır $^{15}$. Hesap, eğitimli, dil bilen, yeni sporlarla tanışma fikrine açık, seyahat imkânı olan, mekân ve etkinlik tercihleriyle görece üst-orta sınıf genç erkeklerin sosyalleşme mecralarındandır. Hesabın idealize ettiği erkekliğin odağında kendini gerçekleştirmek vardır. Bu açıdan deneyimlenen ya da deneyimlenmesi arzulanan erkekliğin sınıfsal bir kendini inşa hali olduğu, diğer erkekliklerden yaşam tarzı üzerinden ayrımanın hedeflendiği söylenebilir. Bu hedef, ekonomik ve kültürel sermayenin erkeklikler arası deneyimleri farklılaştııışına da örnektir. Hesap, egemen erkeklik kodlarını bütünüyle reddedişi, kadınlarla mutlak eşitlik savunusu ve LGBTi+ mücadelesini sahiplenen içerikleriyle diğerlerinden ayrilır. @erkekkanali, ataerkilliğin zedelediği sağlıklı erkekliği bulmayı öğütler ancak egemen erkeklik pratiklerinin özü kaybetme ile ilişkilendirilmesi, doğallaştırmacılığa yaklaşma potansiyeli de taşımaktadır. Erkek kurtuluşçu söyleme sahip hesap, içerimli erkeklik kavramı üzerinden tartışılmaya da açıktır.

Içeriklerinin teması, "kırmızı haplı"16 erkekliğin sırları olan @erkekadamsitesi, 02.10.2017'den beri içerik üretmektedir. Gönderilerde kadınlar takas edilebilir basit şifreli metalara, sürekli planlar kuran şeytani varlıklara indirgenirken, erkekleri onların tuzaklarına karşı aydınlatma kutsal bir amaca dönüştürülmektedir. Kadının şeytani çekiminden tılsım muamelesi yapılan taktiklere, bilgeye sunulan şükrandan gerçeküstü kahramanlık hikayelerine dek fantastik bir dünya inşa edilmiştir. Red pill, next, rebound, delta gibi güncel erkeklik jargonuna içkin terimlerin kullanıldığı, kadınlar ve erkeklerin özelliklerine ait kodlarla hesaplamaların yapıldığı gönderilerdeki bilimsellik iddiasıyla bilginin hiyerarşisi yeniden üretilmektedir. "Erkekadam"lık, "feminenin oyunundan ne bekleyeceğinizi bilecek tecrübeye sahip olmak, bu oyunda ustalaşmak"la tariflenmekte; kadınların planlarını bozguna uğratmak ve tercih edilen olmak için yarışmak yinelenmektedir ${ }^{17}$. Mahmut Abi ve Üstad olarak da anılan, takipçilerinin ilişki süreleri veya ilk mesajlarını dahi danıştıkları hesap yöneticisinin onayı erkek cemaatinden dışlanmamanın aracına dönüşmüştür. Yönetici, 'gerçek erkek' olarak görmediği kişilere dair fikirlerini paylaşmayı takipçilerin yorumları ile katıldığı bir erkeklik ritüeline dönüştürür. Ona daha iyisini yapma sözünü veren erkek, dışlandığı bu ritüele kabul edilme arzusunu da ilan etmiş olur. Hesapta maskülinite güçlü bir kasa benzetilir; "kolay ve zorluktan arınmış ortamda" erimemesi için, baskı ve zorluğu kabullenerek güçlenmesi gerektiği belirtilir" ${ }^{18}$. Feminizm, "asıl amacı, kadın cinselliğinin önündeki tüm engelleri kaldırırken erkek cinselliğini tamamen kısıtlama"19 ve "sadece \#intikam alma ve tazminat ödetme hareketi" 20 olarak tanımlanmaktadır. İçinde bulunulan krizin en net ifade edildiği paylaşımlar feminizme dair olanlardır. Kay-

15 https://www.instagram.com/p/B2oNCeuAMYE/

16 Red Pill- Blue Pill nitelemeleri, Matrix (Wachowski \& Wachowski, 1999) filmine referansla kullanılır. Filmin kahramanı Neo mavi hapı seçerse yanılsama içindeki hayatına devam edecek, kırmızı olanı seçerse zorluklarla yüzleşmek pahasına aydınlanacaktır. "Red Pill felsefesi"nin, erkekleri feminizmin manipülatif eşitlik söylemlerine karşı uyandırdığı savunulur.

17 https://www.instagram.com/p/B60TmYJnbgq/

18 https://www.instagram.com/p/B1VZOe5HduG/

19 https://www.instagram.com/p/BhrJ1tJlsYF/

20 https://www.instagram.com/p/BuOkNusHi5」 
gıyı azaltmanın bir yolu olarak, "bir feminist nasıl tedavi edilir?"21 isimli görseller ve feministlere cinsel saldırıda bulunan failleri öven iletiler ${ }^{22}$ paylaşmaktır. Kadın cinayeti failleri, gerçek erkek olamamış özgüvensizler olarak tariflenir: "iç̧inizdeki mavi haplıyı öldürün. O birini öldürmeden" ${ }^{23}$. Suçlu erkeklerle bu yolla ayrışılırken "erkekadam"lığın kusursuzluğu yeniden kutsanmaktadır. Nadirliği vurgulanan "erkekadam"lığa atfedilenler hegemonik erkeklik nitelikleriyle örtüşmektedir. Hesap doğrudan kadın, özellikle feminizm, düşmanı söylemiyle maskülisttir.

Iletilerindeki iki tema, nafakaya odaklanarak erkeğin hukuk önünde hiçleştirildiğine dikkat çekmek ve kadın cinayetlerinin karşısına görünmeyen erkek cinayetlerini yerleştirmek olan @1maskülist, 21.06.2019'dan beri içerik üretmektedir. Kadın cinayetleriyle ilgili eylemler ve 6284 sayılı kanun hesabın hedefindedir. "6284 rezaletinin yarattığı mağduriyetler" 24 ifadesiyle karşı çıkılan kanun ile "iftiraya kurban giden erkek sayısının her gün arttığı" 25 iddia edilmektedir. "Ardında milyonlara varan mağdur bırakan İstanbul Sözleşmesi" 26 kadın cinayetlerinin sebebi olarak sunulur, katil erkeklerin kadın beyanının esas alınması sonucu mağdur olduğu yinelenirken "çoğu cinayet vakası bu tür sorunlara maruz kalmış kişilerin sonunda bir vahşet yaratmasıyla sonuçlanmış" ifadelerine yer verilir27 . "Mantıklı düşünebilen herkes, bunların tek derdinin Avrupa Birliği fonları olduğunu bilir"28 iletisinde de görüldüğü gibi, kadın cinayetlerine karşı örgütlenen derneklerin fonlar üzerinden ithamı düşman imgesinin boyutunu değiştirmektedir. Fon aldığı iddia edilen feministler dış düşman, medya, akademi ve hukuk iç düşmanlar olurken, erkeklik işgal edilen vatanı savunu üzerinden anlamlandırılmaya başlar. Kadın cinayetlerine yalnızca eylemler eleştirilirken değinilmektedir. Cinayetler bu yolla görünmez kılınıp, eylemler kriminalize edilirken komşu kavgasından akran zorbalığına dek erkeklere yönelen her şiddet olayı gündemde tutulur. Hesabın içerikleri, müphem bir düzenin erkekliği parçalayıp yok edeceği fikri ve kadına yönelik nefret söylemiyle biçimlenmektedir. Maskülist söyleme sahip hesap, kadın düşmanı ve feminizm karşıtı erkeklerin sosyalleştiği bir alan kurmaktadır.

Çalışmanın yazım aşamasında kapanan @erkekcemiyeti isimli hesap 31.08.2019'dan beri içerik üretmektedir. Hesabın içerikleri, erkekliğin yenilmekte olduğu bir dünyada zafer kazanma çağrısıyla düzenlenmektedir. Kadınlar galip gelinmesi gereken rakip/düşman, ilişkiler kuralına göre oynanması gereken sınav/ savaş olarak kurgulanmaktadır. Gerçek erkek, kazandıkları haklarla yetinmeyen kadınların saygıyı hak etmediğinin bilincinde olandır: "Kadınlara aşırı bir saygı ile davranmak tek kelimeyle gülünçtür ve böyle bir şey bizi onların gözünde küçük düşürür". Hesapta, feminizmin yarattığı tahribatın hukuk, medya ve akademi eliy-

21 https://www.instagram.com/p/BaLJLjFnbfr/

22 https://www.instagram.com/p/BteG8wOHnCp/

23 https://www.instagram.com/p/B3/42leHljH/

$24 \mathrm{https} / / / \mathrm{www}$.instagram.com/p/B8oX2A6nClX/

25 https://www.instagram.com/p/B6WHhiPH2bN/

$26 \mathrm{https} / / / \mathrm{www} \cdot$ instagram.com/p/B83gzUNnOVx/

27 https://www.instagram.com/p/B2bE4BaHZBo/

28 https://www.instagram.com/p/B83_aV_n40d/ 
le meşrulaştırıldığı ve "girl power propangandası ile narsizmin pençesine düşen kadınların cinsel pazar değerlerini gülünç duruma düşecek kadar abartııkları" savunulur. Erkeklik, şiddet gören kadına yardım ederken şiddetin hedefi olan erkeklere dair haberler üzerinden üretilir. Şiddet görerek kimliğini aşağılatan erkeğe duyulan öfke, kurallardan cayanın akıbetini aşağılayarak yansıtıır; erkekliğin kutsal sınırları, 'o olmayış'la, yeniden çizilir. Hukukun "kadınların erkeklerin hayatını karartmasını kolaylaştırdığı" vurgulanmaktadır. Örneğin, "kadına pişman olduğu sekse tecavüz deme" hakkını tanıyan feministlerin güdümündeki hukuk ve medyadır. Feminist içerik üreten sitelere atıfla, "bireysel silahlanma ve dövüş sporlarını bu yüzden tavsiye ediyorum" iletisi paylaşılır. Kadınlardan, özellikle feministlerden, küfürler ve saldırgan cinsel içeriklerle söz etmek hesabın rutinidir. Radikal bir maskülist söyleme sahip @erkekcemiyeti, feminizmi erkeklerin tüm sorunlarının yegâne sebebi olarak işaretlenmektedir.

İdeal erkekliğin gereklerine dair bilgiler içeren görsellerden oluşan @erkekgibi_ isimli hesap 03.03.2020'den beri içerik üretmekte ve erkeklerin temel sorununun, ilişkide erkek lehine sonuç alamamak olduğunu iddia etmektedir. Bu sorunun çözümünü kadınların eksiklerini görmek ve duyguların galibiyetini engellemekte bulan hesap, seslendiği "kırmızı haplılar" için rota oluşturur: "Oyun, karşındaki kişiye belirli duyguları yaşatmanın ardından onu ErkekGibi kontrol altına almaktan ibaret diyebiliriz"29 . Bu içerikte görüleceği gibi, ilişkiler oyun, kadınlar şifreleri kolaylıkla çözülecek hedeflerdir. "Mavi haplı", "kırmızı haplı" nitelemeleri ideal erkeklik kıstasları olarak kullanılmakta ve ideal erkeklik, sürekli teste tabi kararlııkla yüceltilmektedir: "Her kadın ilişsi öncesi ve sonrasında sizin ErkekGibi davranışlarınız konusunda emin olmak ister. Eğer zayıf bir çocuk gibi davranırsanız, kadınlar sizi asla erkeği olarak görmeyecektir"30. Güçlü erkeklik nitelikleri "erkeğin cinsel pazar değeri" olarak şöyle sıralanmaktadır: "Instagram profilinin kalitesi, iş hayatındaki başarı, beden dilin, giyimine gösterdiğin özen, vücudunun estetikliği gibi maddelerce sıralanabilir" ${ }^{31}$. @erkekgibi_'nin, erkekler arası dayanışmadan çok erkekler arasındaki rekabetin altını çizen söylemiyle diğer hesaplardan ayrıldığını söylemek mümkündür. Hesap, erkekleri yok sayılan dezavantajlarında eşitlemek yerine sürekli rekabet halinde oluşlarında ortaklaştırmakta ve bunu bir toplumsal baskı olarak okumamaktadır. İçerikler, maskülist söylemle oluşturulur.

İçerikleri, çoğunlukla kadınlardan taraf erkeklerle ilgili haberlerden oluşan @ masculinity.tr, 02.08.2019'dan beri üretim yapmaktadır. Kimliğine yabancılaşmış olarak nitelenen bu erkekler takipçilere kadın egemenliğinin sorumluları olarak sunulur; hem o olmamanın gururu hem de ona duyulan öfkede yarışla "gerçek erkeklik" yeniden üretilir. Erkekler, bilincinde olmalarından bağımsız olarak, kadınların yaşattığı şiddette eşitlenirler ancak bu şiddete karşı tutumları onları birbirlerinden ayırır: Hesabın işaret ettiği biçimiyle "biz"; gerçek erkekler, "alfalar", "kırmızı haplılar" ve ötekiler; "Meriçler", "mavi haplılar", "betalar". Erkeklik

29 https://www.instagram.com/p/B_OvCTInAZw/

$30 \mathrm{https} / / / \mathrm{www}$.instagram.com/p/B9g4et8nOYB/

31 https://www.instagram.com/p/B_OvHURHQNp/ 
"duyguların esaretinde" değil disiplinli yaşayabilenlerin hak ettiği bir kimlik olarak konumlandırııı: "Sağlıklı, yetişkin bir erkek romantik (duygusal) olamaz"32. Hesabın ideal erkeklikle ilişkilendirdiği nitelikler doğrudan hegemonik erkekliğe içkin niteliklerdir: "Karar verici, kendi yolundan şaşmayan, fiziksel güç ve sağlığının doruğunda, zihnini sürekli besleyen, kendine güvendiği için kontrol manyağı olmayan, kadınları etkilemeye çabalamayan, sorumluluk sahibi" 33 . Kadınlar, "Kadınlar doğası gereği çıkarcıdır" 34 , "Kadınlar mantıksız ve tutarsızdır" 35 iletileri ile aşağılanırken, feministlerin "erkekleri kadınların kapı paspası kadar yapmaya götüren propagandalar" ile "erkeklerin güçlü olmasını sağlayan ayrıcalıkları elde etmek" istediği söylenir. "Kırmızı haplılar" düşmanlaştırılan kadınlara karşı başarıya güdülenir. Erkeklikler arası hiyerarşi, 'biz'in 'öteki'ni aşağılayışıyla kurulmaktadır. Akademi, hukuk, feminist örgütler, kadınların doğası yani bir bütün halinde dünyanın erkekleri acizleştirmek için çabaladığı savunulur. Hesabın gerçek erkeklik tanımı hegemonik erkekliğe atfedilen niteliklerle bütünüyle örtüşür. Egemen erkeklik dışındaki deneyimleri tanımayan hesap, maskülist söyleme sahiptir.

Görsel yoğun bir tasarıma sahip @maskulizmturkiye hesabı 18.05.2017'den beri içerik üretmektedir. İçeriklerin odağında, erkeklerin maddi imkânlarını kullanmak başta olmak üzere, her tür kötülüğü bünyesinde barındırabilen şeytanlaştırılmış kadınlık ve cinsel özgürlük talebini ilan ederek yaşayacağı şiddeti hak eden kadınlık olmak üzere iki temel temsil yer almaktadır. Cinsellikle ilişkilendirilen kadınlığın daha aşağıda konumlandıııdığı görülmektedir. Kurgu olması mümkün ekran görüntüleri "yorumsuz" iletisiyle paylaşılarak takipçilere, kadınları hedef alan şiddet, tecavüzle ıslah hayalleri kurabilme, kimliklerini duydukları nefrette üretebilme imkânı sunulmaktadır. Hesap, takipçilerinin bu tarz gönderilere verdiği etkileşimle diğerlerinden ayrımaktadır. Erkeklere "erkek doğdukları için özür diletmeyi" hedeflediği iddia edilen feminizm ${ }^{36}$, nefret söyleminin odağındadır. Bir çocuğu yalnızca bakarak etkileyebilen feministlerin olduğu görsellerle, her an her yerde olabilen tehlikeli bir düşman imgesi çizilir ${ }^{37}$. Doğaüstülük atfederek insani anlamlarından, akli yetilerinden sıyırmaya çalıştıkları bu imgenin kendilerinde yarattığı kaygıyı azaltmaya çalışırken görünür kılmaktadırlar. Erkeklerin içinde bulunduğu konumun sorumlusunun "feminaziler" ve "kadın düşkünü erkekler" olduğunu dile getirilir. Bu erkekleri yaşama hakkını dahi yitirmemek için feministlere karşı uyanık olmaya çağıran @maskulizmturkiye radikal biçimde maskülist söyleme sahiptir.

Erkeklerin dezavantajlı konumunu açığa çıkarma iddiasındaki @Maskulendusunce, 14.06.2019'dan beri içerik üretmekte ve "Erkeklerin ikincil cinsiyet sayıldığı ve yasal haklarının önemsenmediği bir çağdayız, bunu değiştirmek bizim elimizde" ifadeleri ile yitirildiği iddia edilen ayrıcalıkları geri kazanma stratejilerine

32 https://www.instagram.com/p/B3lz7/Nnn5F/

33 https://www.instagram.com/p/B08oLzhgm2v/

$34 \mathrm{https} / / / \mathrm{www}$.instagram.com/p/B2d_I1YnG-o/

$35 \mathrm{https} / / / \mathrm{www}$.instagram.com/p/B2d3nOYHMJB/

36 https://www.instagram.com/p/BUPH60NALkF/

37 https://www.instagram.com/p/BWoOa3nFQvU/ 
yoğunlaşmaktadır. Mavi /kırmızı haplıık karşılaştırmaları bu hesapta da yer bulmakta ve ideal erkekliğin kendini önceleyen, cinsel açıdan aktif erkeklik olduğu yinelenmektedir. Buna yaklaşamayan "dișileşmiş erkeğimsiler"38, bir yandan öfkeyle aşağılanıp erkeklik cemaatinden kovulurken diğer yandan erkek iktidarını güçlendirmek için saflara çağrılmaktadır. Kadınlarla erkekler arasındaki eşitsizliğin kaynağına tatmin olmayan kadınlık yerleştirilir: "Kendi karını düşünmüyen, başkaları için yaşayan erkeğimsiler (yani dişileşmiş) ve isyankar, kötücül, empati yeteneği hiç olmayan, kendini hep haklı ve mağdur kadınlar türüyor. Denge tamamen bozuluyor"39. Erkeklik değer hesaplamaları ile tariflenir, kadınlarla kurulan ilişkiler bu değere katkılarıyla anlamlanırlar. "Kadın peşinde koşmak toy erkek erkeklerin yapacağı iştir ve değerinizi çok düşürür. Erkeğin yapacağı mental-duygusal-fiziksel olarak güçlü olmaktır"40. Bu hesaplamalarda kadınlar, sürekli ilana muhtaç cinsel aktifliğin kimliksiz nesneleridir: "Ben bir erkeğim ve cinsel intiyaçlarımı karşılamayan bir kızla gereğinden fazla oyalanmam zayıf kişilikli bir olduğumu gösterir" ${ }^{41}$. Hesap, kadınları "dişiler" ve feministler olarak ikiye ayırır ve takipçiler, "biraz daha güçlense seni otobüste arka koltuk hariç oturtmayacaklar" 42 ifadesiyle "insanlık düşmanları" olarak nitelendirilen feministleri tanımaya çağrılır. Erkeklik ayrıcalıklarının yitiminden duyulan kaygının zirvesine yerleştirilen feministler asla ilişkilenilmeyecek kadınlar, dişiler ise kötücüllükle erkekliği eksiltecek canlılar olarak temsil edilir. Dişi nitelemesi, karşıt ötekinin kadınlığından değil topyekûn insanlığından sıyrımasını sağlarken ondan gelecek tehlikeyi de bertaraf etmektedir. Doğa-akıl ikiliği üzerinden üretilen bu kurguda, akıldan sıyrılmış, çıkar odaklı doğasına uygun hareket eden dişi, akılla donanmış, üstün nitelikli erkeğin karşısında mağlubiyete mahkumdur. Egemen erkeklikten bir adım uzaklaşanları, dişilikle yaftalayarak erkeklikten dışlayan @Maskulendusunce radikal bir maskülist söyleme sahiptir.

Erkeklerin kendilerinden beklenen görevler karşısında yaşadıkları sorunlarla ilgili haberler ve erkeklere yönelik şiddetin görünmezliğine dair yorumlara yer veren @maskulizm_esitlik, 09.09.2018'den beri içerik üretmektedir. Erkekler toplumsal baskıdan çekinerek yaşadıkları şiddeti duyuramadıkları ve kadına yönelik şiddete "erkekliklerinden utanarak" tepki verdikleri için suçlanırlar. Mağduriyete yapılan vurgu ile kimliğe sahip çıkmaya çağrı arasında doğrudan ilişki vardır. Belli fiziki standartlarda olmaya ve ekonomik güce dair beklentiler erkeklerin baskı altına alındığı temel başlıklar olarak görülür. Ancak baskıya, baskı karşısında yaşanan öz-yıkıma dikkat çekilirken fail muğlaklaştııılır. Sorumlu ataerkil sistem değil, "feminaziler" in manipülasyonlarına meyilli, kimliğinin bilincinde olmayan erkekler toplamı olarak kavranan toplumdur. Hesap, LGBTi+ mücadelesine destek verdiğini, heteroseksüel erkekler dışındaki erkeklikleri tanıdığını belirtmektedir ancak bu desteğin daha çok heteroseksüel erkeği tarzı nedeniyle yaşayabileceği baskıdan korumak üzerinden şekillendiği görülmektedir. Erkeklerin sorunlarının, dayatılan kimliği reddedip özgürlük

38 https://www.instagram.com/p/B8jjrBBoZZz/

39 https://www.instagram.com/p/B8jjrBBoZZz/

$40 \mathrm{https}: / / \mathrm{www}$.instagram.com/p/B7YoCC1nkj0/

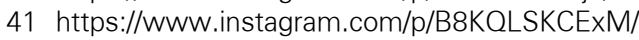

42 https://www.instagram.com/p/B6qAeq-CEg7/ 
talep ederek çözüleceği vurgulanır. Hesap erkek kurtuluşçu bir çizgide durmakla birlikte, feministlere karşı söylemiyle maskülizme yaklaşmaktadır.

\section{Kadınlar ve Feministler}

Erkek kurtuluşçu söyleme sahip @maskulist.tr ve @erkekkanalı isimli hesapların kadınlara ilişkin söylemleri belli noktalarda ayrışmaktadır. @maskulist.tr, kadınların sorunlarının bilincinde olduklarını fakat toplumun aynı duyarlılığı erkeklere göstermediğini belirtmektedir. @erkekkanali ise, kadınların hakkını savunmada daha çekincesizdir. Her iki hesapta da, erkeklik kadınlığın zıddı olarak değil kendiliğindenlikle kurulur. @erkekkanali'nın içerimli erkeklikle okunmaya da imkân tanıyan konumunun kimi zaman kadını tektipleştirmeye, @maskulist.tr'nin ise özellikle kadınların toplumsal gündemlerdeki yerini yorumlarken maskülist söyleme yaklaşmasını yeniden inşanın yöntemsel çeşitliliği üzerinden okumak mümkündür. Connell (2019), erkekliğin kriz eğilimlerini gidermeye yönelik mücadelenin erkeklik kültlerini sahiplenmekten feminist reformları desteklemeye dek farklılaşabileceğine değinmektedir.

Maskülist söyleme sahip hesaplarda, kadınlara yönelik en 'ılımlı' yaklaşım, sorunlarını abartarak toplumu yanlış yönlendirdikleridir. Bu söylemde erkeklik, erkekleri köleleştirmesine rağmen fazlasını talep eden kadınlığa haddini bildirme arzusuyla kurulmaktadır. Eşit bir ilişki, kadının çıkarcı doğası nedeniyle mümkün görünmediğinden, kadının edilgen olduğu ilişkilerden tecavüze uzanan şiddet kurguları erkeklik ispatına dönüştürülür. 'Gerçek erkek', kendisinin iradesiyle başlayan duygusuz ilişkilerde en aktif olanken, kadın onu amacına ulaştırmanın değersiz aracına indirgenir. Tecavüz doğrudan gönderilerde değil, özellikle feministleri ıslah yöntemi olarak, yorumlarda yer bulur. Bu tehdit, cinsel şiddetin "ortak sorumluluk" kavramıyla gerekçelendirildiğine dikkat çeken Scully'den hareketle okunmaya imkân tanımaktadır. Scully (2014, s.151-155), ortak sorumluluğun belli bir kategoriye dahil insanların, bu kategorideki diğer insanların davranışlarından sorumlu olmalarını anlattığını söyler. Failler için ortak sorumlulukla gerekçelendirdikleri cinsel şiddet, "meşru bir intikam ve cezalandırma yolu"dur. Bir kadının yalnızca kadın kategorisinde yer aldığı için şiddetin hedefi olduğu bu durumlarda, erkek için endişe uyandırması, uyması beklenen ahlak kurallarına uymaması, yeterince güvenilir olmaması kâfidir. Erkek kaybettiğini düşündüğü saygınlığı yeniden kazanmak için kadınlarla ödeşir. Maskülist hesaplardaki ıslah etme yarışına dönüşen bu yorumlar, erkeklerin önce kadınlara ardından birbirlerine galip gelmelerinin aracı olmaktadır. Kadınlar sürekli el yükseltilen bir yarışın yok edilmesinden haz duyulan nesneleri olarak görülürler. Gerçek erkeklik kurgusu, ehlileştirildiğini düşündüğü cinsel gücü donanıp, ondan uzaklaşmasını sağlayanlardan; kadınlardan öcünü alarak kendini yeniden üretmekle tariflenir. Kadınların erkekleri sömürmeleri, haklarını ellerinden almak için toplumu yanlış yönlendirmeleri ve özellikle cinsel özgürlük talep etmeleri nedeniyle bedel ödemeleri gerektiği düşünülür. Bu nefret söyleminin gönderilerde değil yorumlarda belirginleşmesini, kadınlardan taraflılı̆ıyla erkekleri köleleştirdiği düşünülen hukuktan kaçışın yolu olarak oku- 
mak mümkündür. Ging (2017), dilediğinde silinebilen anonim profiller sayesinde yasadışı ve düşmanca erkeklik performanslarının daha kolay sergilenebilir olduğundan söz ederken, Red Pill akımının zehirli bir erkeklik tezahürü olarak tüm dünyada yayıldığına değinir.

Fiziki ve cinsel şiddet tehdidinin hedefinde özellikle feministlerin olması şaşırtıcı değildir. Feministler, erkeklerin içinde bulunduğu çıkmazın sorumluları olarak görülür. En 'llımlı' söylemlerde, feministler hukuku, medyayı yönlendirerek erkekler aleyhine politikalar geliştirmelerini sağlamakta, -kalmışsa- masum kadınları ezildiklerine inandırarak yoldan çıkarmaktadır. Erkek cinselliğini yok etmeye, erkekleri yasalar eliyle köleleştirmeye ant içtiği düşünülen feministler aynı zamanda annesinin yanında duran çocuğu bir bakışla etkileri altına alabilen doğaüstü varlıklar olarak temsil edilirler. Bu temsilde cisimleşen kaygıyı, feministleri sürekli aynı şeyleri tekrar eden ancak söylediklerinin bilincinde dahi olmayan kişiler olarak konumlandırarak azaltmaya çalışırlar.

Feministlerin hedefe yerleştirildiği bir diğer başlık, Avrupa fonları ile güçlenerek toplumu parçaladıkları iddiasıdır. Maskülist hesaplara göre feministler, nafaka, uluslararası sözleşmeler, eşitlik talepleriyle aileyi ve toplumu yok etmekle görevlendirilmişlerdir. Dış düşmandan beslenerek kurumları erkek düşmanlığına yönlendiren feministlerin karşısına, aileyi ve vatanını koruyan erkekler yerleştirilir. Aklı olanın kaçınmasını salık verdikleri aile, feministlerle ilişkilendiğinde sahip çıkılması gerekene dönüşmektedir. Vatan ve toplum da bu noktada ayrışmaktadır. Erkekliği hiçleştirmekle suçlanan toplum, feministlerin buyruğuyla hareket eden hukuk, medya, akademi ve bunların manipülasyonlarına kanan insanlar toplamıdır. Toplumu değil saldırı altındaki vatanı savunacak 'gerçek erkeklik', aslında kendi ayrıcalıklarını korumak için girdiği bu savaşta, bir kez daha kahramanlaştırılır. Morley ve Robins (1997, s.75), kimliğin sorununu, ister bireysel ister kolektif olsun, popüler kültürün paranoyak damarı üzerinden okurlar. Buna göre, şiddete dayalı kadın düşmanlığından yabancı kültür/ideolojiye içerideki düşman korkusuyla yaklaşmaya dek çeşitlenen kaygının kaynağında ası 'ben'in yitip gitme korkusu vardır. Bu nedenle, kültürel kimliğin savunulması gayet kolay biçimde, bayağı bir milliyetçiliğe dönüşebilir. Maskülist hesaplardaki saldırı kurgusunda, erkekliğini yitirmiş Batı, eril Doğu'yu, üstelik kadınlara sağladığı fonlarla, fethetmeye çalışmaktadır. Maskülist hesaplar, kendilerinin köleleştirmeye boyun eğmemek olarak niteledikleri ancak ayrıcalıklarını yitirme korkusuyla biçimlenen kriz dinamiklerini savaş olarak algılamaktadır. Zafer kazanmanın yolunun, uzaklaşılan 'gerçek erkeklik'i yeniden kuşanmaktan geçtiğine inandıklarından kolektif kimliği bu erişilmesi güç kurguyu kutsayarak üretirler.

\section{İdeal Erkeklik Atıfları}

Erkek kurtuluşçu hesaplarda ideal erkeklik, egemen erkeklik değerleri ve toplumsal baskıyı reddetmekle biçimlenmektedir. Bu nedenle başta heteroseksüel cinsel yönelim dışındakiler olmak üzere, egemen olmayan erkeklik- 
leri tanır ve seviyesi farklı olmakla beraber, LGBTì+ mücadelesini gündemde tutmaya çalışırlar.

Maskülist hesaplarda ideal erkeklik, kadınların (şeytani ya da cadı) doğaüstülükle temsilinde, bilge-toy erkeklikler arasındaki hiyerarşide, erkekliğin hep tırmanılması gereken zirveyle kurgulanmasında da açığa çıktığı gibi, kahramanlıkla ilişkilidir. İlişkileri savaş/ erkeklik sınavı, kadınları galip gelinecek düşmanlar olarak nitelemek de bu kurguyu beslemektedir. "Dişi”" olarak anılan kadınlar veya erkekliğine sırt çeviren "dişileşmiş erkekler", yok edilerek erkekliği güçlendirecek avlar olarak konumlandırılır. Kurgu olması muhtemel görsellerdeki kötücül kadın imgeleri ve erkeklerin boyunlarında tasmalarla gezdiği dünya tahayyülleriyle çilekeşlik reddediliyor görünürken kutsanır, kriz var olanla mesafeyi açar. Gerçek erkeklik ideali, gerçekle bağını yitirmiş erkekliğin kahramanlık destanına dönüşmektedir. Bourdieu (2014, s. 69-70), "eril değerlerin yüceltilmesi, dişillikle harekete geçirilen korku ve endişelerde kendini karanlık tarafta bulur" der, şerefin kırılganlığının bedene bürünmüş hali olarak kadınların "şeytansı kurnazlık"ları nedeniyle erkeklik her daim saldırıya açık görülür. Erilliğin görünürlüğünü arttıran dövüş sporları, askerlik, toplu tecavüz erilliğin kırılganlığından beslenir ve şiddet "gerçek erkekler grubuna aidiyet" in tasdikine dönüşür. İdeal erkekliği kazanılacak zafer ya da erişilecek zirve olarak konumlandıran maskülist hesaplarda da, şeref yalnızca 'şeytani kadın'a galibiyetle tahkim edilmez, o galibiyeti sağlayacak koşullar örgütlenir.

Maskülist hesaplarda ideal erkeğin 'gerçek erkeklik' dışındaki deneyimlerin aşağılayıcılığının bilincinde olduğu vurgulanmaktadır. Kadınlara saygı, ilgi duymak, tek eşliliği tercih etmek ya da baskıcı erkeklik rollerini reddetmek, "alfa"lık veya “kırmızı haplı"lığın dışında kalmak, 'biz'in 'öteki'si olmak için yeterlidir. 'Gerçek erkeklik' ona ulaşmak için sürekli çaba gerektiren doğasıyla sahiplenilir, onu kazanmak için kutsanmış bir çilecilikle acı çekmek gerektiği yinelenir. Maskülinite sürekli basınç hissetmezse eriyecek bir kasa benzetilir, ideal erkekliğin gereği olarak görülen kas, erkeklik ile inşadaki acıda özdeşleştirilir43. Duygudan arınmış, cesur ve acıya dayanıklı olmak gerçek erkekliğin temel değerleridir, ekonomik güç ve kariyer, erkekler arası rekabetin aracı olarak daha az önemsenmektedir. Sosyoekonomik konumu ikincilleştirip bedene ve duygu duruma yatırımı öngören bu kurguyu, uğradığını düşündüğü saldırı karşısında hattını olabildiğince güçlendirme çabası olarak okumak mümkündür. Söylemin üreticileri, mozaik erkekliği (Coles, 2009) örnekler biçimde ataerkiden almayı umdukları payı arttırmak için, ekonomik güce oranla daha kolay sağlanabilir olan nitelikleri sahiplenmektedir. Erkeklik sıklıkla duygudan arınmış cinsel aktiflik üzerinden üretilir ancak bu aktiflik asla evlilikle ilişkilendirilmez, evlilik kadınların güdümündeki hukukun yasallaştırdığı kölelik olarak görülür. Yaygın hegemonik erkeklik niteliklerinden olan evliliğin reddi, kategorilerin sınırlarının yeniden düzenlenmeye açıklığı üzerinden okunmaya elverişlidir. Diğer yandan bu hesaplarda tariflenen değerler genel olarak hegemonik erkekliğe işaret etse de, rızanın değil zorun önemsemesi ile toksik erkekliğin deneyimlendiği de söylenebilir (Messerchmidt, 2019 s, 90).

43 https://www.instagram.com/p/B1VZOe5HduG/ 
Maskülist hesaplarda, ideal erkeklik söyleminin yeniden üretildiği başlıklardan bir diğeri, kadın cinayetleridir. Kadın cinayetleri ancak yoğun toplumsal tepki anlarında kadınların abarttığı bir sorun olarak yaftalanmaktan çıkmaktadır. Bu noktada söylem, olduğu ilan edilenle öykünülen arasında bölünür. Egemen erkekliklerinin aşkın deneyimlerini paylaşan hesap yöneticileri cinayetlere, katilin fiziki veya ekonomik üstünlüğüne dikkat çekerek, kadınların mükemmeli arayıp yaşadıklarını hak ettikleri iması ile tepki vermektedir. Bu tepkinin açığa çıkardığı sancılı konum, ataerkil düzenden yeterince pay alamadığını düşünen erkeğin mesaisini üzerine kurduğu erkek olmadığıyla yüzleşmesiyle ilişkilidir. Yüzleşmenin kurgusal kimliği çatlatmamasını tek yolu, öykündüğü ve olduğu düşündüğü erkekliği temize çıkarmaktır. Bunun için katil erkeklerin kendilerine biçilen kadükleştirilmiş erkekliği kabullenen özgüvensiz kişiler oldukları ilan edilerek hem 'gerçek erkeklik'in kusursuzluğu kutsanır hem de bir bütün halinde erkeklik bir kez daha kadınların kurbanı olarak temsil edilir.

\section{Erkekliğe Dair Sorunlar ve Çözüm Önerileri}

Erkek kurtuluşçu söylemi benimseyen hesaplarda erkekliğin temel sorunları, ideal erkeklik kurgusu kategorisinde de değinildiği üzere, toplumun erkeklere atfettiği görevlerdir. Erkekliğin sanıldığı kadar avantajlı bir konumda olmadığını açığa çıkarmaya çalışırken özellikle medyayı erkeklerin deneyimlerini görünmez kılıp, egemen erkeklik değerlerini ve buradan doğan tahakkümü kutsamakla suçlamaktadırlar. @erkekkanali daha çözüm odaklı bir yaklaşımla, erkeklere kendilerini gerçekleştirmelerini, aşağı gördükleri bir toplumsal konumlanışın simgesi olan şiddet faili erkekliğe sırt çevrilmelerini öğütler. @maskulist.tr sünnet, askerlik, işsizlik, iş cinayetlerine dair içeriklerle, erkekliğe içkin saydığı sorunları görünür kılma amacındadır. @maskulist.tr'yi diğer hesaplardan ayıran en önemli başlık, toplumsal cinsiyet eşitsizliğinin ataerkil sistemin sorunu olduğunu dile getirmesidir. Çözüm önerisiyse, erkeklerin erkekliğe atfedilen rolleri reddetmesidir.

Maskülist söyleme sahip hesaplarda erkekliğin temel sorunu, kadınlık lehine bozulan denge olarak görülür. Buna göre, kadınlar önce erkekleri çıkarları için sömürür ardından yönlendirdikleri kurumlar aracılığıyla sömürüyü meşrulaştııır ve erkekleri şiddet bağlamında tektipleştirip daha fazla hak talep ederler. Erkeklerin sorunlarının nihai çözümü, hep daha fazlasını isteyen kadınlar ve kadınların hizmetinde olması dışında neye işaret ettiği muğlak bir toplam olan topluma dersini vererek gerçek erkekliği tanıtmaktır. Kadınlardan taraf olmayı seçerek kimliklerine yabancılaşan erkekler bu galibiyet anından mahrum bırakılacak olanlardır. Kadınların yaşadığı şiddete müdahil olurken şiddet gören erkeklere ait görüntülerin, gerçek erkekliğin hanesine atılan çiziğin bedeli olarak, sevinçle paylaşılması bundandır. Bu görüntülerin, kadına şiddete karşı duyarlılı̆ın yükseldiği günlerde gündeme gelmesi tesadüfi değildir, maskülist hesaplarda kimlik, erkek cemaatinden dışlanma korkusuyla üretilir. 


\section{Erkekliğin Gelecek Tahayyülü}

Erkek kurtuluşçu söyleme sahip hesaplar, erkekliğe dair sorunları bugünkü durumdan hareketle değerlendirdiklerinden, sorunların çözüldüğü ya da sürdüğü bir gelecek tahayyülleri yoktur. Ancak maskülist hesaplar için erkekliğin gelecek mekânı fantastik bir evrendir. Güncel durumun vahameti, gerçek erkeklerin sayısı azaldıkça daha kötü günlerin geleceğini ilan eden yorumlarla paylaşılmaktadır. Erkeklerin erkek düşmanı kadınlar ve toplumu durduramadıkları gelecek tahayyülünde erkeklik, otobüsün en arka koltuğuna bile oturtulmamaktan erkek cinselliğinin tamamen kısıtlanmasına dek hiçleştirici pratiklerle deneyimlenmektedir. Hukukun kadın lehine tutumunun güçlenişiyle bu kurgunun yasal bir gerçeğe dönüşmek üzere olduğu iddia edilmektedir.

Erkeklerin gelecek tahayyülü, incelenen hesaplarda en az değinilen ancak erkekliğin kriz dinamiklerinin en net biçimde okunabildiği temadır. Krizin temel dinamiği, cinsel özgürlüğe sahip kadınların daha da güçlenerek erkek cinselliğini yok edecek olmasına dair kaygıdır. Egemen erkekliğin zirvesi olarak temsil edilen, çalışmaya konu hesaplardan bazılarının yalnızca 'taktik'lerine odaklanan içerikler hazırladığı sınırsız cinsel gücün yitmesi, uğruna savaşılan en güçlü kalenin düşmesi anlamına gelecektir. Bu yitim intimali, köleleştirme söyleminin de zeminidir. İ̆diş edilmiş erkeklik alışageldiği efendilik statüsünü yitirecektir. Egemen erkekliğin tarihsel arka planıyla okunabilecek olan köle- efendi ikiliği, sıklıkla yinelenen dış düşmanların vatanı parçalayacağı paranoyasından hem beslenmekte hem de onu derinleştirmektedir.

\section{Sonuç}

Zaman-mekân farkını ortadan kaldırarak görece eşitlik imkânı sunan sosyal medya geniş kitlelerce erişilebilirliğiyle toplumsal deneyimleri doğrudan yansıtan bir alandır. Kullanıcılarının kurgusal kimlikler yaratmasına imkân sağlayan yapısı ile özgürleşmenin ya da egemen kolektif kimliğe içkin söylemleri yeniden üreterek tahakkümün güçlendirilmesinin aracı olabilmektedir. Bu mecradaki erkeklik temsilleri de, gündelik yaşamda deneyimlenen 'gerçek' cinsiyet hiyerarşisinin sanallığını yitirmiş bir devamı oluşu ya da özellikle heteroseksüellik dışı cinsel yönelime sahip erkekliklerin norm-dışı cinsiyet/cinsellik pratiklerini ilan edişiyle, benzer bir yapılanışa sahiptir.

Her an her yerdeliği ve kendisinde ilan edilmeyen deneyimin yaşanmamış sayııışıla son yıllarda gerçek ve sanal dünyalar arasındaki ayrımı muğlaklaştıran sosyal medya uygulamalarından biri olan Instagram, genç yoğun kullanıcı profili ve toplumsal cinsiyet kimliklerini beklentilere göre şekillendirilmeye etkisiyle kimliklerin deneyimlenişini incelemek için verimli bir çalışma alanı sunmaktadır. Kriz dinamiklerinin işsizlik gibi yapısal sorunların yanı sıra feminist hareketin etki alanın artması ve egemen erkeklik dışındaki erkeklik deneyimlerinin görünür olmasıyla derinleştiği bir gündemde, sürekli kaygı yüklü bir kimlik olan erkekliği Ins- 
tagram'da incelemek hem krize anın içinden bakma hem de erkekliklerin gelecek tahayyüllerine dair fikir verme potansiyeli taşımaktadır.

Instagram'da üretilen erkeklik söylemlerini, temsil edilen erkeklik kategorisi ve aidiyet duyulan erkeklik hareketlerini açığa çıkarma amacıyla betimleyen bu çalışma kapsamında incelenen hesaplardan ikisinin erkek kurtuluşçu hareketin söylemlerine, sekizinin ise -altısı radikal olmak üzere- maskülist söyleme sahip olduğu görülmüştür. Çalışmanın varsayımı ile uyumlu olarak, maskülist olarak konumlanan sosyal medya hesaplarında erkeklik krizinin bertaraf edilmeye çaıışıırken görünür kılındığı tespit edilmiştir. İçerik üretmeye başladıkları tarihler, erkekliğin kriz dinamiklerinin Türkiye'ye özgü deneyim süreçleriyle örtüşen bu hesapların söylemleri de zaman içinde daha da radikalleşmiştir. Özellikle, 8 Mart, 25 Kasım gibi kadın mücadelesi için önemli tarihler ya da kadına yönelik şiddetin gündemde olduğu süreçlerde içerikler nefret söylemiyle biçimlenmiştir. Karşı-hegemonyanın sesi yükseldikçe kriz de derinleşmiş ve söylem hegemonyayı yeniden inşa üzerinden kurulmuştur.

Egemen erkeklik dışındaki erkeklik deneyimlerine alan tanımayan bu hesaplardaki erkeklik temsilleri hegemonik erkeklik ile toksik erkeklik arasında salınmaktadır. Kimi zaman aynı hesabın art arda yaptığı paylaşımlarda ortaya çıkabilen bu sabitlenememe hali, erkeklik kategorilerinin erkeklikler arası müzakere ve mücadele süreci olarak tanımlanmasını da örnekler niteliktedir. Söylemlerinin içerdiği şiddetin boyutu değişmekle birlikte maskülist hesapların krizi egemen erkekliğe atfedilen değerleri yücelterek ve feministlerde cisimleşen bir kadın düşmanlığı üreterek aşmaya çalıştıkları görülmektedir. Bu hesaplar için, kadınlar ve erkekler arasındaki ilişkiler, kadınların kötücül doğaları sayesinde önde oldukları bir oyun/ sınav/savaştır ve gerçek erkekliğin deneyimlenmesi sürekli galibiyete bağlıdır. Kadınların bir avı andııı biçimde dişi olarak anıldığı bu kurguda gerçek erkekliğin temel niteliği cinsel güç olarak işaretlenmekte ve bu güce ait vurgu, özellikle cinsel özgürlügünü ilan ederek krize yeni bir boyut katan feministleri ıslah için cinsel saldırı tehdidiyle zirveye ulaşmaktadır.

Maskülist hesapların biricik düşman imgesi olarak feministler, dış düşmanların fonlarıyla medya, akademi, hukuku da yöneterek erkekliği ve ülkeyi yok etmekle görevli militanlar olarak tariflenmektedir. Özellikle hukuk, erkeğin köleleştirilme sürecine yasal zemin hazırladığı algısıyla hedefe yerleştirilmektedir. Düşmanın, başta cinsel güç olmak üzere, erkekliğe dair tüm nitelikleri elinden alacağı korkusuyla beslenen erkekler, maskülist hesaplarca gerçek erkek olmaya çağrımaktadır. Bu çağrı, kadınların şifresi basit varlıklar olmaya indirgendiği hesapların yöneticilerinin kendilerini, erkekleri tehlikelerle dolu dünyaya hazırlamakla görevlendirmeleri anlamına da geldiğinden, erkekler arası hiyerarşinin bir kez de sosyal medya aracıı̆ğıla kurulmasını sağlamaktadır. Hem Instagram profili kalitesinin gerçek erkeklik niteliklerinden birine dönüşmesi hem de kendisinin egemen erkekliği de anonimlik nedeniyle muğlak hesap yöneticilerinin birer erkeklik bilgesi olarak konumlanışı, sosyal medyanın sanal-gerçek yapısına dair veriler de sunmaktadır. 
Çalışma kapsamında incelenen erkek kurtuluşçu söyleme sahip iki hesabın takipçi sayıları nedeniyle listenin başında yer alması genç kullanıcı kitlesine sahip Instagram'da temsil edilen erkekliklerin konumuna dair gerçekçi bir çıkarıma olanak sağlamaz zira kolektif kimliğin yeniden üretimi takipçi sayılarından ziyade yorumlarda sağlanmaktadır. Maskülist hesaplardaki yorumlarda fiziki ve cinsel şiddetle ıslah tehditleri, takipçi erkekler arasında galibiyet iddiasına girerek yarışılan birer oyuna dönüştürülmekte ve egemen erkeklik hem kendi zaferinden emin erkekler için bireysel olarak hem de bir erkeklik ritüeline dönüştürülerek kolektif olarak yeniden üretilmektedir. Maskülist söylem, sosyal medyanın anonimlik imkânının açtığı alanın da etkisiyle, dünyadaki seyrine paralel olarak Türkiye'de de anti-feminist bir hatta yerleşmektedir. Anonimliğin etkisi, bu hesaplardaki inşanın önemli bir bölümünün yorumlarda üretilmesinde de görülmektedir. Hesap yöneticileri hukuken sorun teşkil edebilecek konuları yorumlara taşıyarak, kadınların bedenleri, fikirleri, eylemleri varlıklarıyla aşağılandığı birer erkeklik kutsama törenine alan açmaktadır. Maskülist hesaplardaki yorumların egemen erkekliğin yeniden üretimine etkisinin incelenmesi ve -varsa- bu hesaplardaki düşmanlaştıııcı söylemlere yönelik hukuki yaptııı veya cezasızlık süreçlerinin takibi bu çalışmanın önerileridir.

\section{Kaynakça}

Alemdaroğlu, A. ve Demirtaş, N. (2004). Biz Türk erkeklerini böyle bilmezdik!: Mynet'te erkeklik halleri. Toplum ve Bilim. 101, 206-224.

Akbaş, E. (2012). Türkiye'de sosyal medyada futbol taraflarının erkeklik söylemleri. Yayımlanmamış yüksek lisans tezi, Bilgi Üniversitesi.

Bourdieu, P. (2014). Eril Tahakküm. (B. Yılmaz, Çev.). İstanbul: Bağlam.

Bozok, M. (2009). Feminizim erkekler cephesindeki yankısı: Erkekler ve erkeklik üzerine eleştirel incelemeler. Cogito. 58, 269-284.

Bozok, M. (2011). Soru ve cevaplarla erkeklikler. İstanbul: Sosyal Kalkınma ve Cinsiyet Eşitliği Politikaları Merkezi Derneği.

Coles, T. (2009). Negotiating The Field of Masculinity: The Production and Reproduction of Multiple Dominant Masculinities, Men and Masculinities, 12(1). Erişim 4 Nisan 2020,

https://journals.sagepub.com/doi/10.1177/1097184X07309502

Connell, R.W. (1998). Toplumsal Cinsiyet ve Iktidar. (C. Soydemir, Çev.). İstanbul: Ayrıntı.

Connell, R.W., Messerschmidt, J.W. (2005). Hegemonic Masculinity: Rethinking the Concept. Gender \& Society, 19 (6). Erişim 20 Ocak 2020, https://journals. sagepub.com/doi/10.1177/0891243205278639

Connell, R. (2012). Masculinity Research and Global Change. Masculinities and Social Change, 1(1). Erişim 6 Şubat 2020, https://hipatiapress.com/hpjournals/ index.php/mcs/article/view/157 
Connell, R.W. (2019). Erkeklikler. (N. Konukcu, Çev.). Ankara: Phoenix.

Demez, G. (2011). Sanal Dünyanın Kişisel Alanı: Bir Sosyal Paylaşım Ağı Olarak Facebook'ta Erkek(lik) Tartışmaları. i. Erdoğan (Ed.), Medyada hegemonik erkek(lik) ve temsil içinde (325-352). İstanbul: Kalkedon.

Doruk, Ş. (2019). Narsist bir sunum biçimi olarak erkeklik: Sosyal medyada çıplak beden. Yayımlanmış yüksek lisans tezi, Mimar Sinan Üniversitesi.

Elgün, A. (2020). Erkek Evreninde Erkeklik Biçimlerinin Temsili: erkekadam.org Üzerine Nitel Bir Analiz. Erciyes Illetişim Dergisi. 7(7 ), 871-894.

Elgün, A. (2020). Dijital Kültürde Erkeklik (ler): Instagram \#erkeklik Üzerine Bir içerik Analizi. Turkish Studies, 15(2), 912-941.

Erkol Günay, Ç. (2018). İllet, zillet, erkeklik: Eleştirel erkeklik çalışmaları ve Türkiye'deki seyri. Toplum ve Bilim. 145, 6-31.

Feltman, C.E. (2018). Instagram use and self-objectification: The roles ofinternalization, comparison, appearancecommentary, and feminism. Yayımlanmamış Doktora Tezi, University of Tennessee.

Garlick, S. (2010). Taking Control of Sex? Hegemonic Masculinity, Technology, and Internet Pornography. Men and Masculinities. 12. Erişim 4 Nisan 2020, https://journals.sagepub.com/doi/10.1177/1097184X09341360

Ging, D. (2017). Alphas, betas, and incels: Theorizing the Masculinities of the Manosphere. Men and Masculinities 2017. Erişim 19 Mart 2020, https://journals. sagepub.com/doi/abs/10.1177/1097184X17706401?journalCode=jmma

Gökaliler, E., Özer, A. (2019). Baba 2.0. Dijital Dönüşüm ile Değişen Baba Rolü Üzerine Bir Araştırma. Iletişim Kuram ve Araştırma Dergisi, 4, Bahar 2019. Erişim $17 \mathrm{Ha}$ ziran 2020, https://iletisimdergisi.hacibayram.edu.tr/index.php//KAD/article/view/570 Hooks, B. (2018). Değişme isteği, Erkekler, Erkeklik ve Sevgi. (Z. Kutluata, Çev.). İstanbul: bgst.

Light, B. (2013). Networked Masculinities and Social Networking Sites: A Call for the Analysis of Men and Contemporary Digital Media. MCS - Masculinities and Social Change. 2-3. Erişim 27 Mart 2020, https://hipatiapress.com/hpjournals/ index.php/mcs/article/view/762

Messner, M. (2016). Forks in the Road of Men's Gender Politics: Men's Rights vs Feminist Allies. Internation Journal of Crime, Justice and Social Democracy, 2016 5(2). Erişim 7 Nisan 2020, https://www.crimejusticejournal.com/article/view/800

Messerschmidt, J.W. (2019). Hegemonik Erkeklik Formülasyon, Yeniden Formülasyon ve Genişleme. (Eleştirel Erkeklik İncelemeleri İnisiyatifi, Çev.) İstanbul: Özyeğin Üniversitesi Yayınları.

Morgan, E.M., Richards, T.C., VanNess E.M. (2010). Comparing Narrativies of Personal and Prefferred Partner Characteristics in Online Dating Advertisements. 
Computers in Human Behavior. 26 (5). Erişim 9 Mayıs 2020, https://www.sciencedirect.com/science/article/abs/pii/S074756321000018X?via\%3Dihub

Morley, D. ve Robins, K. (1997). Kimlik Mekanları Küresel Medya, Elektronik Ortamlar ve Kültürel Sınırlar. (Çev. E. Zeybekoğlu, Çev.) İstanbul: Ayrıntı.

Mowlabocus, S. (2007). Gaydar: Gay men and the pornification of everyday life. K.Nikunen, S. Paasonen, L. Saarenmaa (Ed.), Pornification: sex and sexuality in media culture içinde (61-72). Berg: Oxford.

Onur, H., ve Koyuncu, B. (2004). Hegemonik erkekliğin görünmeyen yüzü: Sosyalizasyon sürecinde erkeklik oluşumları ve krizleri üzerine düşünceler. Toplum ve Bilim. 101, 31-49.

Öztürk, F. E. (2021). İnternet Alt Kültürü Bağlamında Hegemonik Erkelik Söyleminin Dijital Dönüşümü: \#erkekyerinibilsin Hastag Örneği. Global Media Journal TR Edition. 11(22), 101-123

Patton, M.Q. (2014). Nitel araştırma ve değerlendirme yöntemleri. Ankara: Pegem Akademi.

Rodriguez, N.S., Hernandez, T. (2018). Dibs on That Sexy Piece of Ass: Hegemonic Masculinity on TFM Girls Instagram Account. Social Media + Society, January-March 2018. 1 Mart 2020, https://journals.sagepub.com/doi/ full/10.1177/2056305118760809

Sancar, F. (2016). Toplumsal cinsiyet çalışmalarına erkek katıımı: Bir sosyal medya platformu olarak ErkekMuhabbeti. Yayımlanmamış yüksek lisans tezi, Yaşar Üniversitesi.

Sancar, S. (2009). Erkeklik: İmkansız iktidar ailede, piyasada ve sokakta erkekler. İstanbul: Metis.

Scully, D. (2014). Cinsel Şiddeti Anlamak Tutuklu Tecavüzcü Erkekler Üzerine Bir Inceleme. (Ş.Tekeli, L. Aytek, Çev.). İstanbul: Metis.

Selek, P. (2018). Şiddetin öznesini kurmak ya da erkek yapmak. Toplum ve Bilim. 145, 130-137.

Verrastro, V., Fontanesi, L., Liga, F., Cuzzocrea, F., Gugliandolo M.C. (2020). Fear the Instagram: Beauty Stereotypes, Body Image and Instagram Use in A Sample of Male and Female Adolescents. OWERTY 15, 1. Erişim 7 Haziran 2020, http:// www.ckbg.org/qwerty/index.php/qwerty/article/view/318

Yang, C.C. (2000). The Use of the internet Among Academic Gay Communities in Taiwan: An Exploratory Study. Information, Communication \&Society. 3:2. Erişim 4 Nisan 2020, https://www.tandfonline.com/doi/ abs/10.1080/13691180050123686.

https://www.instagram.com/maskulist.tr/

https://www.instagram.com/erkekkanali/ 
https://www.instagram.com/erkekadamsitesi/

https://www.instagram.com/1 maskulist/

https://www.instagram.com/erkekgibi」

https://www.instagram.com/masculinity.tr/

https://www.instagram.com/maskulizmturkiye/

https://www.instagram.com/maskulendusunce/

https://www.instagram.com/maskulizm_esitlik/ 